\title{
Peningkatan Pemahaman Program Bermain Anak Indoor Dan Outdoor Di Desa Koto Tuo Kecamatan Batang Peranap
}

\author{
Raihana*, Alucyana, Bahril Hidayat, Ihya Syafira, Wirdatul Jannah \\ ${ }^{1}$ Fakultas Agama Islam, Universitas Islam Riau \\ email: raihana@fis.uir.ac.id
}

\begin{abstract}
The teaching and learning process in kindergarten uses more games to transfer knowledge to children However, in some kindergartens there are still learning and teaching processes that provide Student Worksheets (LKS) to improve children's abilities. One of them is in Koto Tuo Village, Batang Peranap Subdistrict, Indragiri Hulu, found 2 kindergartens that still provide student worksheets for the learning process and minimal in granting the game. In general, children learn through playing in an indoor environment, but actually playing can also be done outdoors. Indoor and outdoor games are a form of play that is commonly used in PAUD institutions. The method of implementation in this service is 1) Provision of knowledge through counseling. 2) Training on making Educational Game Tools (APE). The result of this activity is an increase in teacher and parent knowledge about the importance of providing games to children both indoor and outdoor games to improve children's development at school.
\end{abstract}

Key words: Early Age, Learning, Play, Indoor, Outdoor

\begin{abstract}
Abstrak
Proses belajar mengajar di TK lebih banyak menggunakan permainan untuk transfer pengetahuan kepada anak. Namun di Beberapa TK masih dijumpai proses belajar mengajar memberikan Lembar Kerja Siswa (LKS) untuk meningkatkan kemampuan anak. Salah satunya di Desa Koto Tuo Kecamatan Batang Peranap, Indragiri Hulu, ditemukan 2 TK yang masih memberikan LKS kepada siswa untuk proses pembelajarannya dan minim dalam pemberian permianan. Pada umumnya anak belajar melalui bermain dalam lingkungan indoor, namun sebenarnya bermain anak juga bisa dilakukan di outdoor. Permainan Indoor dan outdoor merupakan bentuk permainan yang biasa digunakan di lembaga PAUD. Metode pelaksanaan dalam pengabdian ini adalah 1)Pemberian pengetahuan melalui penyuluhan. 2) Pelatihan pembuatan Alat Permainan Edukatif (APE). Hasil dari kegiatan ini adalah adanya peningkatan pengetahuan guru dan orang tua tentang pentingnya pemberian permainan pada anak baik permainan indoor ataupun outdoor untuk meningkatkan perkembangan anak di sekolah..
\end{abstract}

Kata Kunci: Usia Dini, Pembelajaran, Bermain, Indoor, Outdoor

\section{PENDAHULUAN}

Pendidikan awal di masa kanakkanak memiliki peran yang vital bagi pertumbuhan dan perkembangan anak selanjutnya. Albert dan Miller berpendapat bahwa dalam pengembangan program kegiatan bermain (kurikulum) bagi anak usia dini seharusnya sarat dengan aktivitas bermain yang mengutamakan kebebasan bagi anak untuk bereksplorasi dan beraktivitas, sedangkan orang dewasa (orang tua dan guru) seharusnya lebih berperan sebagai fasilitator pada saat anak membutuhkan bantuan untuk memecahkan masalah yang dihadapi (Yuliani, 2011)

Menurut NAEYC Early Chilhood Program Standar (2018) terdapat dua hal yang penting tentang kurikulum bagi anak usia dini, yaitu: 1) Program kegiatan bermain anak usia dini diterapkan berdasarkan kurikulum yang berpusat pada anak serta dapat mendukung kegiatan 
pembelajaran dan perkembangan pada setiap aspek baik estetika, kognitif, emosional, fisik,bahasa dan sosial. 2) Kurikulum berorientasi pada hasil dan mengaitkan berbagai konsep dan perkembangan anak.

Program kegiatan bermain anak bisa berupa pengembangan pada perkembangan sosial emosional, perkembangan bahasa, perkembangan literasi awal, pengenalan matematika, memahami diri sendiri, perkembangan seni dan perkembangan fisik. Meskipun disebut program kegiatan bermain tetapi tetap harus memperhatikan tujuan pendidikan dan memperhatikan tujuan pendidikan, pertumbuhan dan perkembangan anak usia dini dalam segala aspek. (Sujiono \& Nurani, 2011). Dalam program kegiatan bermain ini yang terpenting adalah anak merasa sedang bermain bebas bukan dipaksa untuk belajar.

Membiarkan anak untuk mengekplor sendiri pengetahuan yang diinginkan anak lewat dunianya yaitu bermain, hal ini sejalan dengan pendapat Suyanto (dalam Inayah, 2005) bahwa esensi pembelajaran pada PAUD adalah bermain. Pada umumnya anak belajar melalui bermain dalam lingkungan indoor, namun sebenarnya bermain anak juga bisa dilakukan di outdoor.

Permainan Indoor dan outdoor merupakan bentuk permainan yang biasa digunakan di lembaga PAUD, permainan indoor dimaknai sebagai tekhnik permainan yang dilaksanakan oleh anak usia dini di dalam ruangan kelas, sementara permainan outdoor adalah permainan yang dimainkan di luar ruangan atau di luar kelas.

Berikut beberapa manfaat permainan indoor dan outdoor yang bisa dilakukan oleh anak. a) Permainan Indoor. Permainan indoor tidak begitu melelahkan karena tidak banyak menggunakan aktivitas fisik tetapi lebih kepada aktivitas keterampilan motorik halus yang lebih mengembangkan kreativitas pada diri anak yang dapat membantu pertumbuhan dan perkembangan anak. Permainan indoor juga lebih mengedapankan penggunaan alat media maupun non media tergantung pengajaran yang dilakukan, seperti alat peraga, gambar tema dan lain sebagainya. b) Permainan Outdoor. Berbeda dengan permainan indoor, permainan outdor lebih menekankan pada aktivitas fisik dan motorik kasar anak. Motorik kasar anak berfungsi melatih keterampilan, keseimbangan dan semua gerakan tersebut terkordinasi dengan otak sehingga pelaksanaan aktivitas motorik kasar anak juga mampu untuk melatih otot fisik anak.

Saat ini masih banyak kita melihat orang dewasa (orang tua dan guru) mengabaikan aktivitas bermain pada anak usia dini baik di sekolah maupun di rumah. Bagi guru dalam survei awal tim pengabdi menyatakan bahwa tuntutan dari orang tua siswa yang mengharapkan anak-anak mereka ketika selesai dari TK sudah bisa membaca dan berhitung yang membuat guru mengabaikan aktivitas bermain anak disekolah. Sementara bagi orang tua dalam interview awal tim pengabdi mengatakan bahwa jika anak tidak bisa membaca dan berhitung di SD, anak akan ketinggalan dari anak-anak yang lainnya.

Pada beberapa TK tuntutan orang tua ini diwujudkan dalam bentuk memberikan pembelajaran berupa Lembaran Kerja Siswa (LKS) yang isinya berupa menulis, berhitung dan lain lain. Begitu juga dengan TK yang berada di Desa Koto Tuo Kecamatan Batang Peranap yang juga menggunakan LKS dalam proses pembelajarannya dibanding bermain. Ditambah lagi dengan minimnya pengetahuan guru tentang program kegiatan bermain anak yang bisa mengasah tumbuh kembang dan kreatifitas anak usia dini.

Hal ini menjadi permasalahan tersendiri bagi dunia Pendidikan Anak Usia Dini, karena sejatinya masa Anak Usia Dini yaitu usia 4-6 tahun anak tidak melakukan akativitas belajar seperti anak SD dan SMP, tetapi aktivitas belajar mereka dilakukan dengan bermain. Aktivtias belajar sambil bermain tersebut tertuang di dalam 
kurikulum PAUD yang disebut dengan program kegiatan bermain anak usia dini.

Unsur utama dalam pengembangan program kegiatan bermain anak usia dini adalah bermain. Dalam kurikulum pendidikan anak usia dini kegiatan anak belajar sambil bermain yang sengaja direncanakan untuk dapat dilaksanakan dalam rangka menyiapkan dan meletakkan dasar-dasar bagi pengembangan diri anak usia dini.

Dari survey awal yang dilakukan tim pengabdi di TK yang terletak di Desa Koto Tuo Kecamtan Batang Perapan Kabupaten Indrgiri Hulu, jelas tampak bahwa guru tidak memiliki cukup pengatahuan tentang program kegiatan bermain apa saja yang bisa diberikan kepada anak usia dini, baik kegiatan bermain di dalam ruangan ataupun kegiatan bermain diluar ruangan, sehingga sehari-harinya anak hanya diberikan pembelajaran bernyanyi dan sesekali mengisi lembar kerja siswa yang sudah disediakan oleh Sekolah.

Jika hal ini terus dibiarkan maka kedepannya anak tidak memiliki kreatifitas dan tumbuh kembang sesuai dengan usianya anak. Padahal diketahui kreatifitas menurut beberapa ahli sangat erat kaitannya dengan kognisi atau proses berfikir karena melibatkan kemampuan menghasilkan banyak gagasan, kemampuan menggunakan berbagai macam cara untuk mengatasi masalah, kemampuan mencetuskan gagasan asli yang unik, kemampuan hal detail, memiliki rasa ingin tahu yang tinggi, imajinatif, berani mengambil resiko serta menghargai hasil. (Kaufman \& Sternberg dalam Psychologymania.com, 2006)

\section{METODE PENGABDIAN}

Metode yang digunakan dalam pelaksanaan kegiatan pengabdian masyarakat ini adalah menggunakan metode pendekatan komunitas dalam hal ini komunitas yang dimaksud adalah guruguru TK dan orang tua siswa di Desa Koto Tuo. Pendekatan komunikatas diwujudkan dalam bentuk penyuluhan kepada guru- guru TK dan pelatihan pembuatan Alat Permainan Edukatif (APE) khususnya APE untuk permainan yang bisa digunakan di indoor dan outdoor.

Adapun tahap kegiatan yang dilakukan meliputi tahap persiapan, tahap pelaksanaan dan monitoring evaluasi. Tahap Persiapan dimulai dari Peneliti berkordinasi dengan kepada Desa Koto Tuo dan Kepala Sekolah TK yang ada di Desa Koto Tuo sekaligus melaksanakan survei awal melihat permasalahan apa yang ada di Desa Koto Tuo dan 2 TK yang ada Desa Koto Tuo dan melakukan rencana kegiatan yang akan dilakukan. Tahap pelaksanaan meliputi penyuluhan program kegiatan bermain anak usia dini indoor dan outdoor di Desa Koto Tuo Kecamatan Batang Peranap dan juga praktek pembuatan APE untuk permainan indoor dan outdoor. Sedangkan untuk tahap monev berupa praktik pembuatan alat permainan indoor dan outdoor yang teorinya sudah disampaikan pada tahap penyuluhan serta lembar evaluasi kepada peserta, dimana peserta wajib mengisi form lembar tersebut.

Tabel 1. Tahap Kegiatan Pengabdian

\begin{tabular}{|c|c|c|}
\hline No & Tahapan & Kegiatan \\
\hline 1 & $\begin{array}{l}\text { Tahap } \\
\text { Persiapan }\end{array}$ & $\begin{array}{l}\text { o Identifikasi masalah } \\
\text { Survei awal untuk } \\
\text { mengetahui } \\
\text { permasalahan apa yang } \\
\text { o Berkordinasi dengan : } \\
\text { - Kepala Desa Koto Tuo } \\
\text { - Kepala Sekolah TK } \\
\text { ada di Desa Koto Tuo. }\end{array}$ \\
\hline 2 & $\begin{array}{l}\text { Tahap } \\
\text { Pelaksanaan }\end{array}$ & $\begin{array}{ll}\circ & \text { Penyuluhan } \\
\circ & \text { Pelatihan Pembuatan } \\
& \text { APE Permainan } \\
\end{array}$ \\
\hline 3 & $\begin{array}{l}\text { Tahap } \\
\text { Evaluasi }\end{array}$ & $\begin{array}{lll} & \text { Memberikan } & \text { form } \\
& \text { evaluasi } & \\
\circ & \text { Praktik } & \text { Pembuatan } \\
& \text { APE } & \end{array}$ \\
\hline
\end{tabular}

Peserta dalam penyuluhan dan pelatihan ini terdiri dari guru-guru TK dan orang tua siswa, dengan tujuan agar informasi dan ketrampilan yang didapat tidak hanya di ketahui dan dipahami oleh guru TK saja tetapi juga dipahami oleh semua orang tua yang menyekolahkan anaknya di TK tersebut. 


\section{HASIL DAN PEMBAHASAN}

Kegiatan pengabdian masyarakat ini dilaksanakan dengan beberapa kegiatan yaitu:

1. Penyampaian materi penyuluhan berupa informasi tentang program kegiatan bermain pada anak usia dini dan jenis-jenis permainan indoor dan outdoor yang bisa diberikan kepada anak usia dini.

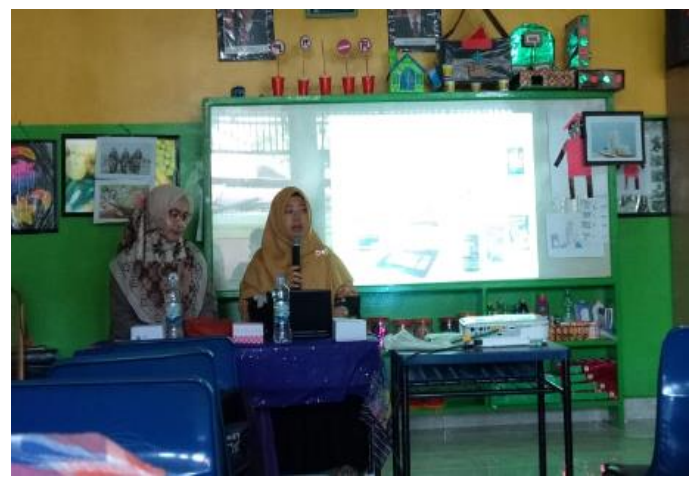

Gambar 1: Foto Kegiatan Penyampaian Materi.

Dalam penyampaian materi penyuluhan banyak pertanyaan dari orang tua mengenai pentingnya memberikan permainan bagi anak usia dini dalam proses belajar mengajar di TK dan di rumah.

Permainan yang diberikan tidak hanya bentuk permainan di dalam rumah saja (indoor), tetapi juga memberikan anak keleluasaan bermain di luar rumah (outdoor) karena anak-anak yang diberi keleluasaan dalam mengembangkan permainan di luar ruangan akan lebih aktif dan reaktif dibandingkan dengan anak yang jarang diberi keleluasaan bermain, selain itu anak juga lebih mudah dalam berinteraksi dengan orang lain, mempunyai jiwa sosial, mempunyai keberanian, imajinasinya yang tinggi dan lain sebagainya.

2. Membuat beberapa Alat Permainan Edukatif (APE) khususnya APE yang bisa di pakai untuk permainan indoor dan outdoor seperti merajut, membuat kura-kura dan statak untuk permainan outdoor.

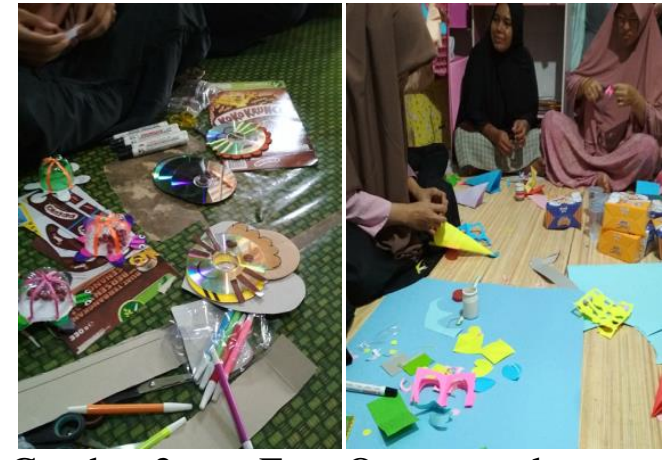

Gambar 2: $\quad$ Foto Orang tua dan guru dalam pelatihan pembuatan APE

Berikut beberapa hasil pembuatan Alat Permainana Edukatif (APE) yang bisa dimainkan di Indoor dan Outdoor.
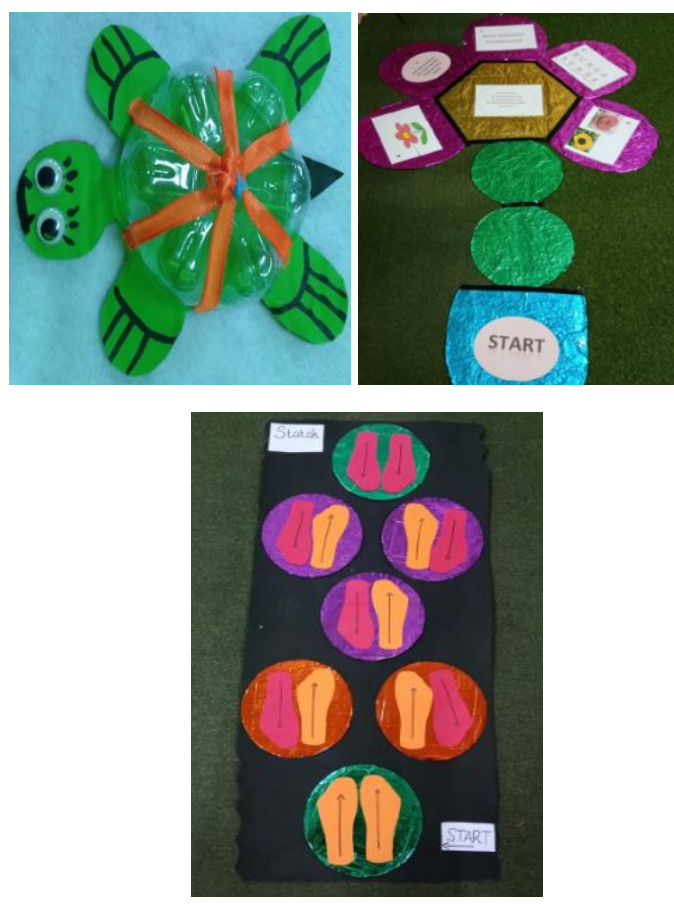

Gambar 3: Hasil Keterampilan Guru dan orangtua siswa dalam pembuatan APE

Ada beberapa hal yang harus diperhatikan dalam pembuatan APE untuk anak usia dini yaitu:

1. Bahan yang digunakan tidak sulit didapat

2. Bahan yang digunakan aman dan tidak berbahaya bagi anak

3. APE yang dibuat mengandung nilai-nilai pendidikan.

4. Dapat difungsikan untuk mengembangkan berbagai aspek perkembangan anak. 
Setelah kegiatan penyuluhan dan pelatihan pembuatan APE dilaksanakan, maka dilakukan evaluasi mengenai kegiatan pengabdian ini, dengan tujuan untuk mengukur tingkat pengetahuan mereka mengenai pentingnya bermain bagi anak usia dini.

Evaluasi yang dilakukan tim pengabdi terdiri dari 2 jenis:

1. Praktik pembuatan Alat Permainan Edukatif (APE) untuk permainan indoor dan outdoor. Dari hasil penyampaian materi tentang jenis dan bahan dalam pembuatan APE yang diberikan kepada guru-guru TK dan orang tua, maka untuk mengukur apakah peserta penyuluhan memahami isi dari materi tersebut, peserta yang terdiri dari guru-guru TK dan orang tua disuruh membuat APE tersebut secara langsung.

Dari hasil pembuatan APE tersebut didapat bahwa seluruh guru dan orang tua yang berjumlah 15 orang mampu membuat APE tersebut sesuai dengan jenis bahan dan bentuk yang sudah dicontohkan.

2. Penyebaran kuesioner kepada seluruh peserta penyuluhan. Hasil evaluasi dari kuesioner yang disebarkan didapat 90,9 $\%$ guru dan orang tua memahami pentingnya bermain bagi anak usia dini baik dirumah maupun disekolah. Sedangkan $9,1 \%$ orang tua dan guru yang masih belum memahami betul bahwa di TK anak usia dini tidak ditekankan dalam hal akademis namun lebih banyak bermain untuk merangsang perkembangan otaknya.

\section{SIMPULAN}

Kegiatan pengabdian masyarakat ini dilaksanakan bertujuan untuk memberikan pemahaman kepada gur TK dan orang tua tentang pentingnya bermain bagi anak usia dini di TK dalam hal proses belajar mengajar. Permainan yang diberikan juga bervariasi tidak hanya sekedar permainan indoor saja tetapi anak juga diberi kebebasan untuk bermain di luar ruangan atau outdoor. Dalam kegiatan ini guru dan orang tua juga di ajarkan cara membuat beberapa Alat Permainan Edukatif (APE) yang permainannya bisa digunakan di indoor maupun outdoor.

Dengan diadakannya kegiatan pengabdian ini guru dan orang tua mengalami peningkatan dalam pemahamannya terhadap program kegiatan bermain indoor dan outdoor apa saja yang bisa diberikan kepada anak, serta pentingnya bermain itu sendiri pada anak dalam proses belajar mengajar.

\section{UCAPAN TERIMA KASIH}

Terimakasih kami ucapkan kepada LPPM Universitas Islam Riau yang telah mendanai program pengabdian masyarakat ini.

\section{DAFTAR PUSTAKA}

[1]. Hasan, Maimunah. 2011. Pendidikian Anak Usia Dini. Yogyakarta: DIVA Press

[2]. Hurlock, E.B. 1978. Child Development. Diterjemahkan oleh Meitasari Tjandrasa dan Muslichah Zakarsih dengan judul Perkembangan Anak. Jakarta: Erlangga

[3]. Innayah. 2012. Media Audio Pembelajaran Untuk Pendidikan Dini dengan Model Permainan. Jurnal Majalah Ilmiah Pembelajaran No.1

[4]. Mansyur. 2005. Pendidikan Anak Usia Dini dalam Islam. Yogyakarta: Pustaka Pelajar.

[5]. NAEYC. (2018). NAEYC Early Learning Program Accreditation Standards and Assessment Items. Printed in United States of America

[6]. Pamadhi dan Sukardi. 2008. Seni Keterampilan Anak. Jakarta:UT

[7]. Puri Aquarisnawati, Dewi Mustami'ah \& Windah Riskasari. 2011. Motorik Halus Pada Anak Usia Prasekolah Ditinjau Dari Bender Gestalt. Jurnal INSAN Vol.13 No.03, Desember 2011.

[8]. Sujiono,Yuliani. 2011. Metode Pengembangan Fisik. Jakarta: UT 
[9]. Sujiono, Yuliani. 2011. Konsep Dasar PAUD. Jakarta: UT

[10]. Kaufman \& Sternberg (psychologymania.com,diakses tanggal 19 Februari 2020). 